\title{
UN Security Council decision-making: testing the bribery hypothesis
}

\author{
Tomada de decisão do Conselho de Segurança da ONU: \\ testando a hipótese do suborno
}

http://dx.doi.org/10.1590/0034-7329201400303

EUGENIO PACELLI LAZZAROTTI DINIZ COSTA*

MARIANA BACCARINI**

Rev. Bras. Polít. Int. 57 (2): 29-57 [2014]

\section{Introduction}

Liberal-institutionalists (LI) (e.g., Martin, 1992) claim that being part of a number of international organizations and/or regimes changes or modifies Great Powers' interests by making the very existence of those relationships a central issue in their agendas; this would severely constrain Great Powers' ability to force their preferences and perspectives upon others' less those relationships might be jeopardized (e.g., Keohane, 1984; Keohane, 1993) ${ }^{1}$. On the other hand, structuralrealists (SR) claim that security issues tower so high above all others that multilateral organizations or regimes will either adjust to international power asymmetries or will become irrelevant or disappear (e.g., Waltz, 1979, 1993, 2000; Grieco 1993a, 1993b, 1995). A more extreme version is that multilateral institutions are simply irrelevant (e.g. Mearsheimer, 2000a, 2000b, 2001).

One way of empirically addressing those claims would be by looking at the inner workings of multilateral institutions. If material benefits (or lack thereof) are consistently related to a more (or less) favorable posture towards more powerful

\footnotetext{
* Department of International Relations at Pontifical Catholic University of Minas Gerais, Belo Horizonte, MG, Brazil (eudiniz@pucminas.br).

** Federal University of Minas Gerais (UFMG), Belo Horizonte, MG, Brazil (marianabaccarini@gmail.com).

1 Sometimes, that claim is severely weakened to become "international institutions matter" (e.g., Keohane \& Martin, 2000). If they bring about minor changes in a state's international behavior, or if its previous interests can be forced upon the other members of a multilateral institution by muscle-flexing or economic inducements, any actor should be more concerned with military and economic capabilities-even more than if that particular multilateral institution didn't exist: one might need material capabilities for previous needs and for addressing its interests in multilateral arrangements. This watered-down claim turns out to be an actual vindication of structural realism strongest claim on institutions - that they actually reflect and even mask capabilities asymmetries—and will not be addressed here.
} 
actors by smaller counterparts, that would be more consistent with Realists than with LI claims; should relatively small actors consistently vote against major donors' interests, that would vindicate institutionalist claims and a powerful rebuke of SR. Intermediate results would be far less conclusive, if at all.

Thus, at the United Nations (UN), should SR have it right, poor countries, highly dependent of international aid, would consistently vote in favor of their major donors, or of those with higher decision power in multilateral aid agencies. Should LI have it right, at least that correlation should not be above average.

Wittkopf (1973) analyzed all votes at the UN General Assembly (UNGA) in 1963 and 1966, the allocation of international economic aid in 1962-1964 and 1965-1967. The association between voting and aid held only for the US and, less distinctively, to the Soviet Union. Only in the case of the US the association was found to be consistently strong over time.

Rai (1980) analyses foreign aid by the US and the Soviet Union to lessdeveloped countries from 1967 to 1976 against voting in the UNGA for 1967, 1970, 1973 and 1976 to test if foreign aid was used (i) as an inducement for similar voting behavior in the UNGA; and/ or (ii) as a reward for similar behavior or punishment for disagreement, concluding that US behavior usually conformed more with the first hypothesis than with the second, and that Soviet aid usually conformed more with the second than with the first.

Lundborg (1998) uses data from 1948 to 1979 to test what he calls a "giftexchange" hypothesis, according to which, during the Cold War, the relative political support to the US in the UN would be positively affected by US aid and negatively affected by Soviet aid; and that US aid would rise if political support for the US were increased, and that Soviet aid would decrease accordingly. This is confirmed by empirical research. On the other hand, this hypothesis would also imply that aid would correlate negatively with income, since the richer's support would be more expensive; this is not confirmed by evidence in a significant way. Lundborg (1998) also tests an "altruistic" hypothesis, according to which an altruistic government would be expected to give a larger aid ratio (defined as aid divided by recipient's income) to countries with a lower per capita income; this evidence is corroborated for both the US and Soviet donating behavior. The findings would support the gift-exchange hypothesis because that would entail that a donor might give aid even if it did not expect it to directly bring political support, but that would be brought about anyway; also, a country might give political support even without expecting a superpower reward, but it would be brought about by the political support anyway. To us, what matters is: aid brings political support, and political support brings more aid from the supported power, and less aid from its rival.

Focusing on voting in the UNGA, Alesina and Dollar (2000) found that the pattern of foreign aid flows is at least partially dictated by political and strategic considerations unrelated to poverty, democracy, sound economic policies and 
less corrupt regimes in developing countries. Analyzing OCDE data from 1970 to 1994, they found that, among the major donors, the USA, Japan, and France observed their political and strategic interests: the USA gives a strong priority to Israel and Egypt (which shows the importance attached to the Middle East)—but, after these, US aid tends to be correlated to poverty, democracy and economic openness; France attaches great importance to its former colonies, and little importance to democracy or poverty; and Japan tends to favor its UN allies and its economic and investment partners.

Fleck and Kilby (2006) have found, among other things, that (i) with caveats, switching one vote from anti-US to pro-US would increase the probability of getting US aid by $0.5 \%$; (ii) higher income reduces the likelihood of receiving US aid; (iii) US exports, US imports and democracy are not statistically significant variables - though this last group of variables seems to be significantly affected by shifts in the US domestic politics. After the Cold War, on the other hand, the importance of the variable "UN voting" seems to have decreased noticeably and has become statistically insignificant.

According to Dreher, Nunnenkamp and Thiele (2008), different forms of aid might differ in their ability to induce political support. The lesser the strings attached to aid, the more valuable it would be for recipient governments- by giving them a freer hand in using it; when donors seek political support, they should grant aid with little or no strings attached to it. Conversely, if donors have in mind goals other than political support, they should prefer program-related forms of aid. Focusing their analysis on US aid and its effects on voting patterns in the UNGA from 1973 to 2002, they conclude that the US uses aid in order to get political support in the UNGA; that when aid is in the form of comparatively more general budget support, agreement with the US was increased; and when analysis is run again only for those issues deemed more important by the US Department of State, the impact of lesser-strings aid would more than double. The results were not replicated for the other G7 donors.

On the other hand, decisions in the UN Security Council (UNSC) are mandatory for every member-state of the UN, and one could therefore expect more intense efforts by major powers to have its preferences attended there than at the UNGA. Unfortunately, it is much more difficult to test the effectiveness of 'getting political support by granting aid' in the UNSC. The different rules and procedures for decision-making in that political body make it quite difficult: ${ }^{2}$ (i) if anything is to be approved, the five permanent members must be in some form of agreement makes it practically impossible to use those votes to assess political affinity; (ii) if some issue is controversial enough, and a major power will veto it anyway, other members may avoid unpleasant political fallout by voting

2 There is a growing literature on UN decision making, both UNGA and UNSC. Besides those specifically addressed here, Fasulo (2009), Jackson (1983), Malone (2004), O’Neill (1996), Prantl (2006), and Smith (2006) have been very useful. 
'yes' and free-riding on the vetoing; (iii) the vetoing power might have an interest in not embarrassing nor increasing political costs for countries which might vote favorably in circumstances in which their votes might actually influence results-at least in the form of having to grant them less concessions in the future; (iv) this is increased by the fact that non-permanent, non-vetoing members have very little potential clout in the UNSC (O'Neill, 1996); (iv) Great Powers, or eventually a sole superpower, can push its preferences by skillful use of exit option (Voeten, 2001): results can't be consistently highly detrimental to a superpower's interest, lest it gets disaffected to the UN and opts out of it, either acting in disregard for it or even leaving it altogether; (v) since the mandatory decisions taken by the UNSC potentially have more impact and consequence, the political costs of posturing are potentially more serious, and that may affect the calculus of voters: whatever influence they might have in the UNSC, it's only temporary, but the consequences of decisions and the capacity of permanent members of affecting them by decisions in the UNSC are not. Therefore, research on that matter has to be more indirect, and less conclusive.

Dreher, Sturm \& Vreeland (2009) use data for 157 countries from 1970 to 2004 to check whether non-permanent members of the UNSC receive more favorable treatment from the World Bank. According to them, results indicate a robust positive relationship between temporary UNSC membership and the number of World Bank projects a country receives, even after accounting for economic and political factors, as well as regional, country and year effects. To them, mainly the US, but also the other major stakeholders of the World Bank definitely use it to try to influence non-permanent members of the UNSC. ${ }^{3}$

Similar claim is made by Dreher, Sturm \& Vreeland (2008), using data for 197 countries from 1951 to 2004 , now addressing the treatment of temporary UNSC members by the International Monetary Fund (IMF). Their results indicate a robust positive relationship between temporary UNSC membership and participation in IMF programs, even after accounting for economic, political, and country-specific factors. There is also evidence that Security Council membership reduces the number of conditions included in IMF programs. To them, mainly the US, but also the other major stakeholders of the IMF definitely use it to try to influence non-permanent members of the UNSC. ${ }^{4}$

A different approach was taken by Kuziemko and Werker (2006b)—from now on, K\&W. They check if temporary membership in the UNSC would bring with it more US aid-directly or more indirectly, via some other multilateral aid

3 Actually, they make a more emphatic claim: “... the projects of the World Bank are one mechanism by which the major stakeholders of the Bank - mainly the US, but also Japan, Germany, France and the United Kingdom — can win the favor of voting members of the UN Security Council', but their evidence doesn't show that they actually win the favor, only that they try to.

4 Again, their more categorical claim that "...IMF loans are one mechanism by which the major shareholders of the IMF-mainly the United States, but also Japan, Germany, France and the United Kingdom - can win the favor of voting members of the Security Council' is not supported by the evidence they bring. 
agencies, and particularly the United Nations Children's Fund (UNICEF). They look at the amount of aid a country received two years before, during and finally two years after membership. They find that in years of high political relevance of the UNSC, temporary members would have their amount of aid significantly increased, when compared to the 2 years immediately before; direct aid by the US might increase by about $170 \%$. Looking at the 2 years immediately after UNSC membership, they also find that, after increasing, the aid did not decrease neither immediately nor sharply. Finally, dictatorships and allies would be more benefitted.

$\mathrm{K} \& \mathrm{~W}$ is an important and groundbreaking paper, and sheds a significant light in the inner workings of the UNSC. But, first, by restricting analysis to two years before, during and two years after temporary membership, one can't be sure that in some other year or years, totally unrelated to UNSC presence, a country, some of them, or all of them didn't have its or their aids increased; second, variation might be due to an overall increase of US or US-controlled multilateral assistance, again not related to UNSC presence. In this paper, we intend to make a preliminary assessment of their claims ${ }^{5}$ by addressing these two points.

The point of doing a preliminary assessment is that, since the literature seems to corroborate SR expectations of the US using the UN, and particularly the UNSC, to advance its own policy preferences, and since a thorough assessment would imply a lot of additional work, we just wanted to check if the results, and particularly $\mathrm{K} \& W$ 's results, would hold if stricter controls were applied. We would just look at the final results and check if everything had gone as we expected if not, then, a full research effort would be in order, because our results would of course not be conclusive. As it will be shown below, our results do not fully corroborate our hypotheses, and they also show the difference brought by stricter measurements of political affinity and aid received, and by considering aid received in all years. Therefore, we decided to publish the preliminary assessment even before running a full analysis with all countries, all years, all votes, all grants.

\section{Hypotheses}

The point here is to make a preliminary assessment of SR and IL claims by keeping a strict control on some variables so as to test the following hypotheses:

H1: The amount of aid a country receives from the US, directly or indirectly, is positively correlated with its political affinity with the US.

A significant correlation between aid and political affinity would be expected by SR: since international organizations would be just another venue to assert

5 We will not address the dictators vs. democracy issue here. 
Great-Powers' traditional, power-politics interests, aid would be granted in exchange for political support. IL would expect at least a weak, non-significant correlation between those variables. A significant, negative correlation between them would be a powerful blow to SR.

H2: The amount of aid a country receives from the US, directly or indirectly, is negatively correlated with its wealth.

This hypothesis is consistent with both SR and IL claims. For SR, the greater the wealth, less important aid will be as a factor to be weighed in when voting; therefore, there would be no incentive for the US to grant them bigger amounts of aid. For IL, membership in an international organization would modify donors' interests and compel them to adjust their behavior in line with the organization's professed goals; since the purpose of granting aid would be to alleviate poverty and/ or contribute to poor countries' development, poorer countries should get more aid. Positive correlation between aid and wealth would be inconsistent with both IL and SR.

H3: Aid receivers would get more aid during its membership at the UNSC, or immediately after, than in years not related to membership, at least if those years of UNSC membership were deemed very important.

This hypothesis addresses one of the methodological problems of K\&W: not controlling for years completely unrelated to UNSC-membership. If aid receivers get more aid in years completely unrelated to that, it would weaken the 'bribery' hypothesis.

\section{H4: All these results should be stronger and more significant until 1991 and weaker and less significant after that.}

Supposedly, with the demise of USSR, there would be both less political relevance for support from the US standpoint and a lack of alternatives from the standpoint of potential aid-recipients, which would lead to an overall decrease in the value of the support-for-aid deal.

\section{Methodology}

Since it's supposed to be only a preliminary assessment, instead of analyzing data for all countries in the UN, we took a sample according to the following procedures: 
- First, we took K\&W data for political relevance of the UNSC., ${ }^{6,7}$

- We then cut off the years 1946 to 1950 , because the hits were unusually high in those exceptional years when the world was adjusting to the end of the Second World War and the UN was being consolidated, and the number of members was too low for current standards.

- After excluding those five years, we selected the highest-ranked years in which Brazil was in the UNSC; this was done, among other reasons (not related to this paper), in order to ensure that there would be at least one UNSC member in a Very Important Year who had belonged to the UN since its beginning and that is also a middle-ranking power, whose capabilities had changed during the period. That gave us the years 1964 and 1993, which respectively ranked eighth and ninth in K\&W's ranking (see Table 1); after the methodological exclusion of 1946-1950, 1964 and 1963 become the third and fourth years in importance. That looked good enough to us.

6 Though we have data for after $2001, \mathrm{~K} \& \mathrm{~W}$ performed their analyses only until then. Since we want to control specifically for those methodological issues, we've decided not to pursue the analysis for years further than that. The sole exception was 2002, in order to assess the 'after UNSC membership' issue.

7 The paper as published in the Journal of Political Economy brought only the graph, but not the data. We thank Prof. Eric Werker for kindly giving us access to the original file. When we performed the same search as they did, there were some slight differences, but not enough to affect the choice and results. Therefore, we kept their original numbers. After that, the decision is straightforward: the 20 highest-ranking years are the Very Important Years; the next 20 are the Somewhat Important Years; and the others are the Not Important Years. 
Table 1. Number of pieces in the New York Times in which the United Nations Security Council is mentioned, with ranking, by year (1946-2001).

\begin{tabular}{|c|c|c|c|c|c|}
\hline Year & NYT hits & Ranking & Year & NYT Hits & Ranking \\
\hline 1946 & 1528 & 2 & 1974 & 203 & 52 \\
\hline 1947 & 1521 & 3 & 1975 & 269 & 39 \\
\hline 1948 & 1535 & 1 & 1976 & 319 & 34 \\
\hline 1949 & 768 & 7 & 1977 & 233 & 50 \\
\hline 1950 & 1062 & 4 & 1978 & 260 & 43 \\
\hline 1951 & 543 & 17 & 1979 & 386 & 27 \\
\hline 1952 & 474 & 20 & 1980 & 348 & 30 \\
\hline 1953 & 450 & 24 & 1981 & 242 & 46 \\
\hline 1954 & 472 & 21 & 1982 & 470 & 22 \\
\hline 1955 & 584 & 12 & 1983 & 235 & 48 \\
\hline 1956 & 563 & 15 & 1984 & 201 & 53 \\
\hline 1957 & 342 & 31 & 1985 & 293 & 37 \\
\hline 1958 & 727 & 10 & 1986 & 178 & 55 \\
\hline 1959 & 250 & 45 & 1987 & 257 & 44 \\
\hline 1960 & 926 & 5 & 1988 & 329 & 33 \\
\hline 1961 & 817 & 6 & 1989 & 185 & 54 \\
\hline 1962 & 276 & 38 & 1990 & 575 & 13 \\
\hline 1963 & 266 & 40 & 1991 & 569 & 14 \\
\hline 1964 & 756 & 8 & 1992 & 676 & 11 \\
\hline 1965 & 517 & 19 & 1993 & 747 & 9 \\
\hline 1966 & 339 & 32 & 1994 & 545 & 16 \\
\hline 1967 & 385 & 28 & 1995 & 314 & 35 \\
\hline 1968 & 460 & 23 & 1996 & 266 & 40 \\
\hline 1969 & 369 & 29 & 1997 & 235 & 48 \\
\hline 1970 & 240 & 47 & 1998 & 521 & 18 \\
\hline 1971 & 425 & 26 & 1999 & 444 & 25 \\
\hline 1972 & 261 & 42 & 2000 & 204 & 51 \\
\hline 1973 & 313 & 36 & 2001 & 130 & 56 \\
\hline
\end{tabular}

Source: Search in the ProQuest database performed by Ilyana Kuziemko and Eric Werke, who kindly shared the file with us. 
Analyzing what happened to countries that belonged to the UNSC in Very Important Years should help ensure that we would meet the phenomenon of moreaid-for-belonging identified by $\mathrm{K} \& \mathrm{~W}$. Therefore, the countries to be examined would be Bolivia; Brazil; Cape Verde Islands; Côte D’Ivoire; Czechoslovakia'; Djibouti; Hungary; Japan; Morocco; New Zealand; Norway; Pakistan; Spain; and Venezuela (Table 2).

Table 2. Number of years of presence at the United Nations (UN) and at the United Nations Security Council (UNSC) for selected countries, 1946-2002.

\begin{tabular}{|l|c|c|}
\hline \multicolumn{1}{|c|}{ Country } & Number of Years in UNSC & Number of Years in UN \\
\hline Bolivia & 4 & 62 \\
\hline Brazil & 16 & 62 \\
\hline Cape Verde Islands & 2 & 33 \\
\hline Czechoslovakia & 3 & 47 \\
\hline Djibouti & 2 & 31 \\
\hline Hungary & 4 & 53 \\
\hline Ivory Coast & 4 & 48 \\
\hline Japan & 16 & 51 \\
\hline Morocco & 4 & 52 \\
\hline New Zealand & 5 & 62 \\
\hline Norway & 9 & 62 \\
\hline Pakistan & 10 & 61 \\
\hline Spain & 6 & 53 \\
\hline Venezuela & 8 & 62 \\
\hline
\end{tabular}

Source: Authors' compilation, from www.un.org

Then, using the same data used by K\&W-the US Overseas Loans and Grants Database, also known as Green Book-, we took the following procedures:

- We summed up all the military aid and economic aid provided every year, according to that database.

- In order to control for variations in the total aid provided, we calculated the average aid by UN member for every year, dividing the total amount of US aid granted each year according to the Green Book by the number of UN members for each year since 1946.

8 Czechoslovakia was split between Slovakia and the Czech Republic in 1992. Since none of these could be deemed the true successor of former Czechoslovakia, the analysis for it runs only until 1992. 
- Then, we calculated the multiple-of-the-average-aid-by-member received each year by every country in our sample, for every year of membership in the UN. That gave us the Share of Total Aid variable for every country of the sample, by year. This would control for fluctuations in the total amount of aid granted by the US throughout the years, directly or through UN multilateral funds. Merely looking at the amount received might obfuscate the fact that, though in a specific year a country might have received a lesser amount of aid, that would be a greater share of the total because, in that year, the total amount of aid granted would have been smaller than in the other year. In the following tables, that is the Share of Total Aid variable.

- We also controlled for variations in each country's share of aid received, because that might be explained by the fact that a particular country could have become richer or poorer; so, we also calculated the Share of Total Aid per GDP per capita variable.

- Finally, we would check the different results against each country's GDP; GDP per capita; and its overall political affinity to the US.

The data for GDP and GDP per capita are somewhat straightforward. We used the Angus Maddison database, ${ }^{9}$ in which those data are available in millions of International Geary-Khamis dollars, or international dollars, adjusted for 1990 and based on both purchasing-power parity and the international price of commodities. To control for fluctuations in the overall economic activity, we divided each sample country's GDP by the world's total GDP for every year since 1946 - that gave us the Share of World GDP variable; and then divided those values by each sample country's population for every year since 1946-the Share of Word GDP per capita variable.

Political affinity was a more difficult task. We therefore developed what we call an Agreement Index, using the database made available by Prof. Erik Voeten. ${ }^{10}$

- We took the votes for every roll call voting in the UNGA for every year, except for 1951 and $1964^{11}$, as coded in the database: 1 to yes; 2 to abstain; 3 to $n o$; 8 to absent; 9 for non-member.

- Then, for every country in the sample, we subtracted the values of each of its voting from the values of the US voting.

- We then counted, for each year, every "0" result-which meant that the country under analysis and the US had voted in exactly the same way-and

9 Available in <www.gdc.net/Maddison/Historical_Statistics/horizontal-file_03-2007.xls>. The data are more easily available there, and international dollars are a better measure than either nominal-exchange-rate dollars or purchase-power-parity only.

10 Available in <http:dvn.iq.harvard.edu/dvn/dv/Voeten>. We thank Prof. Erik Voeten for being so helpful with clarification on the data.

11 There was no roll-call voting at UNGA in those years. 
divided the sum by the total number of roll call votes held in that year. That gave us a Coincidence (with the US) Index.

- We then counted, for each year, every " +2 " and " -2 " result-which meant that the country under analysis and the US had voted in exactly the opposite way - and divided the sum by the total number of roll call votes held in that year. That gave us a Dissidence (with the US) Index. ${ }^{12}$

- Then, for every country, every year, we subtracted the Dissidence Index from the Coincidence Index. Positive results meant that the country under analysis had, in that year, voted more in line with the US than against it; negative results meant the opposite; the value " 0 " meant that it voted as much with as against the US in that year. That is the Agreement Index.

- We then normalized it as a $z$-score ${ }^{13}$ distribution for every year, to account for the possibility that an overall downward or upward trend in favorable votes for the US might be in the air in some period. Therefore, the Agreement Index, $z$-scored ${ }^{14}$ would allow us to compare how much the countries in the sample compared in terms of favorable voting for the US in any particular moment.

We consider the Agreement Index, z-scored a major methodological contribution. First, the Agreement Index in itself is quite more rigorous in measuring political affinity than other indexes, such as those of Marín-Bosch (2004) and that of Lijphart (1963), who include what we might call non-contrary votes (abstentions, excluding absences) ${ }^{15}$. Second, by normalizing it for each year and comparing the year-normalized indexes, we can capture not the absolute distance from the US, but the relative one, controlling for any overall trend of distancing or getting closer to the US by the other members of the UN. This is necessary because one should expect that, as the number of UN members grow, and so does the number of resolutions to be voted, the number of issues would multiply, the number of votes would multiply, not all of them would have the

12 If we performed the same kind of calculation summing up all the other possible results, that would give us a, say, Neutrality Index: for every country, adding the Coincidence Index + Dissidence Index + Neutrality Index would give us the value 1 . But this Neutrality Index serves us no purpose here.

13 That is, we count by how many standard deviations a country's Agreement Index differs from each year's average Agreement Index.

14 We might also call it the "Relative Agreement Index", but Agreement Index, z-scored is a better descriptor for the methodological work.

15 Both authors compute abstentions as a sort of 'half-votes', that is, each vote exactly equal with that of the US would be equivalent with two of those in which of them would abstain. That would give greater number of convergent votes than our Agreement Index. Though there is a good reason for this procedure-an abstention is actually not a disagreement-, that would obscure the possibility that someone might be abstaining in order not to confront another country (e.g., for strictly regional reasons). Since we are concerned here with relative distance, the absolute numbers are of comparatively little relevance than how close a country is with the US - that is why our index is z-scored. Finally, a great number of abstentions and/ or absences can mask a more intense disagreement. In order to capture this, say, net disagreement, we don't include abstentions and absence, and we also subtract the dissident voting from the coincident. 
same importance for the US, the individual cost of each vote would rise, the US would be less willing to, say, increase its 'payment' or 'bribery' accordingly, and countries that would be more prone to trade votes for aid would increasingly 'agree' less, both for immediate reasons ('no reason to vote this way now') and for strategic ones (by not voting accordingly without enough aid, the importance of the 'aid for support' deal is stressed and hammered onto potential donors, from all sides of the political spectrum). ${ }^{16}$

This has major methodological and analytical implications that have not been noticed by other analysts using those data. By not taking into account that trend, some analyses that focus on individual countries ${ }^{17}$ and show them distancing themselves from the US do not realize that, compared to the others, they are actually getting closer to the US. Our Agreement Index z-scored captures and reveals this dynamic. We claim it to be far superior to the other analytical treatments of the subject, at least to our knowledge.

For all that has been said until now, we would expect to find that poorer countries that were politically closer to the US would get a greater share-of-total-aid during its UNSC temporary membership andlor immediately after it (the two years after membership identified by K\&W). Differences within the sample would be due to differences in capabilities and political affinity. In other terms, increases in share-of-total-aid during UNSC membership and share-of-total-aid after UNSC membership should correlate negatively with GDP and GDP per capita, and positively with the Agreement Index, z-scored.

\section{Results}

Overall (1946-2002)

Table 3 resumes the Kendall's and Spearman's Correlation Coefficients ${ }^{18}$ for the Share of Total Aid, Share of Total Aid per GDP per capita, Share of World GDP per capita and Agreement Index, z-scored for the sample countries throughout the period.

16 Actually, this trend is manifestly noticed in the data, but we don't explore it here.

17 See, for instance, Amorim Neto (2012). For a specific discussion of this text, see Oliveira (2012).

18 The Agreement Index, z-scored was effectively normalized for the sample countries, but, for obvious reasons, the Share of Total Aid, Share of Total Aid per Capita, Share of World GDP per capita have not. So, this is not a normal distribution. Therefore, we selected the non-parametric coefficients instead of the more traditional Pearson's Correlation Coefficient, which applies only to normal distributions. 
Table 3. Non-parametric correlation index for Share of Total Aid, Share of Total Aid per GDP per capita, Share of World GDP per capita and Agreement Index, z-scored for selected countries (1946-2002)

\begin{tabular}{|c|c|c|c|c|c|c|}
\hline & & & $\begin{array}{l}\text { Share of } \\
\text { total aid } \\
\text { per GDP } \\
\text { per capita }\end{array}$ & $\begin{array}{c}\text { Share } \\
\text { of Total } \\
\text { Aid }\end{array}$ & $\begin{array}{l}\text { Share of } \\
\text { World } \\
\text { GDP per } \\
\text { capita }\end{array}$ & $\begin{array}{l}\text { Agreement } \\
\text { Index. } \\
\text { z-scored }\end{array}$ \\
\hline Kendall's tau_b & Share of & Correlation Coefficient & - & $.897^{* *}$ & $-.499^{* *}$ & $-.107^{* *}$ \\
\hline & Total aid & Sig. (1-tailed) & - & .000 & .000 & .000 \\
\hline & per capita & $\mathrm{N}$ & 670 & 670 & 670 & 670 \\
\hline & Share of & Correlation Coefficient & $.897^{* *}$ & - & $-.394^{* *}$ & -.054 \\
\hline & Total Aid & Sig. (1-tailed) & .000 & - & .000 & .021 \\
\hline & & $\mathrm{N}$ & 670 & 675 & 675 & 675 \\
\hline & Share of & Correlation Coefficient & $-.499^{* *}$ & $-.394^{* *}$ & - & $.339^{*}$ \\
\hline & $\begin{array}{l}\text { World GDP } \\
\text { per capita }\end{array}$ & Sig. (1-tailed) & .000 & .000 & - & .000 \\
\hline & & $\mathrm{N}$ & 670 & 675 & 675 & 675 \\
\hline & Agreement & Correlation Coefficient & $-.107^{* *}$ & $-.054^{*}$ & $.339^{* *}$ & - \\
\hline & $\begin{array}{l}\text { Index. } \\
\text { z-scored }\end{array}$ & Sig. (1-tailed) & .000 & .021 & .000 & - \\
\hline & & $\mathrm{N}$ & 670 & 675 & 675 & 675 \\
\hline Spearman's rho & Share of & Correlation Coefficient & - & $.982^{* *}$ & $-.685^{* *}$ & $-.153^{*}$ \\
\hline & $\begin{array}{l}\text { total aid per } \\
\text { GDP per }\end{array}$ & Sig. (1-tailed) & - & .000 & .000 & .000 \\
\hline & capita & $\mathrm{N}$ & 670 & 670 & 670 & 670 \\
\hline & Share of & Correlation Coefficient & $.982^{* *}$ & - & $-.564^{* *}$ & $-.091^{* *}$ \\
\hline & Total Aid & Sig. (1-tailed) & .000 & - & .000 & .009 \\
\hline & & $\mathrm{N}$ & 670 & 675 & 675 & 675 \\
\hline & Share of & Correlation Coefficient & $-.685^{* *}$ & $-.564^{* *}$ & - & $.500^{* *}$ \\
\hline & $\begin{array}{l}\text { World GDP } \\
\text { per capita }\end{array}$ & Sig. (1-tailed) & .000 & .000 & - & .000 \\
\hline & & $\mathrm{N}$ & 670 & 675 & 675 & 675 \\
\hline & Agreement & Correlation Coefficient & $-.153^{* *}$ & $-.091^{* *}$ & $.500^{* *}$ & - \\
\hline & $\begin{array}{l}\text { Index. } \\
\text { z-scored }\end{array}$ & Sig. (1-tailed) & .000 & .009 & .000 & - \\
\hline & & $\mathrm{N}$ & 670 & 675 & 675 & 675 \\
\hline
\end{tabular}

** Correlation is significant at the 0.01 level (1-tailed).

* Correlation is significant at the 0.05 level (1-tailed).

Source: Authors' compilation and analyses. 
First, almost all correlations are significant at the 0.01 level, which means that there is less than $1 \%$ probability of it having been achieved by chance. The exceptions are the Kendall's Coefficients for Share of Total Aid (not controlled for GDP per capita), which still are significant at the 0.05 level. When aid is controlled for GDP per capita, we reach the 0.01 significance.

Second, the very strong correlation between Share of Total Aid and Share of Total Aid per capita was thoroughly expected, again for obvious reasons. On the other hand, though in itself a significant, negative correlation between Share of Total Aid and Share of World GDP per capita was also expected (poorer countries should be more sensitive to trade aid for support), the fact that Share of Total Aid per GDP per capita is negatively correlated with Agreement Index, z-scored is inconsistent with the aid-for-support hypothesis (even if it's not a particular strong one ${ }^{19}$, but the sign is unequivocally negative)—except if Share of Total Aid per GDP per capita is consistently highest for UNSC membership at least in important years. That's what now we turn our attentions to (Table 4).

19 Of course, it would be an extremely surprising result if Share of Total Aid per GDP per capita had a strong negative correlation with Agreement Index, z-scored — that would mean that countries were being sort of rewarded by the US for voting against it. That's actually the case for the years after 1991, as shown below. 


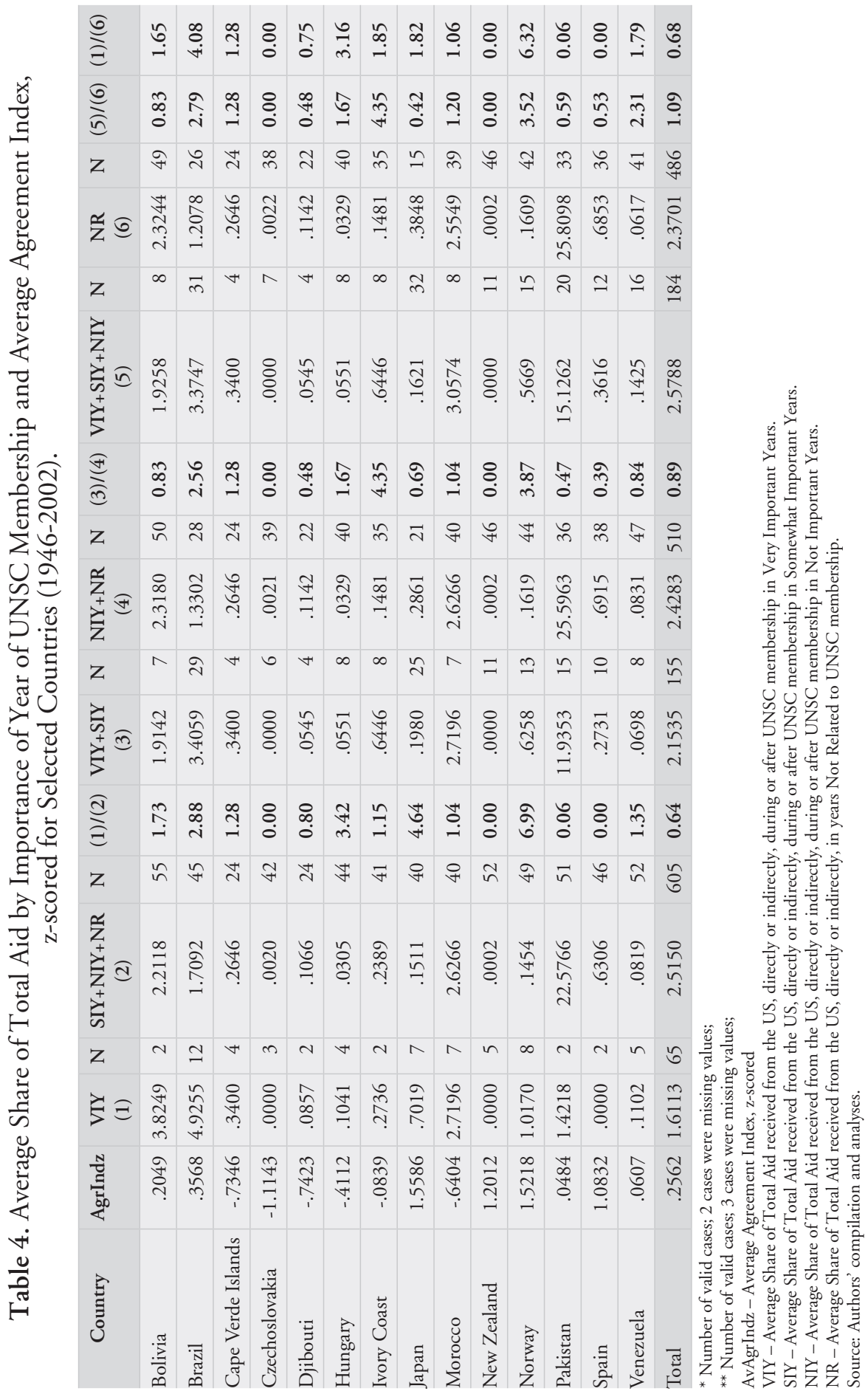


From Table 4, we see that:

- Brazil, Japan and, quite unexpectedly, Hungary (a USSR ally during the Cold War) and Norway (a rich country and NATO member, and in principle less sensitive to the support-for-aid deal) get very much more aid (between almost three to almost seven times) directly or indirectly from the US during or after UNSC membership in Very Important Years than in other years;

- Cape Verde Islands, Venezuela and Bolivia get more aid (between around $25 \%$ to $75 \%$ more), on average, during or after UNSC membership in Very Important Years than in other years;

- Ivory Coast and Morocco get a little more aid, on average, during or after UNSC membership in Very Important Years than in other years;

- contrary to expectations, Pakistan gets astonishing 15 times less aid during or after UNSC membership in Very Important Years than in other years;

- contrary to expectations, Djibouti and Spain also get less aid during or after UNSC membership in Very Important Years than in other years;

- in line with expectations, Warsaw Pact's Czechoslovakia and rich, close US ally New Zealand get no significant amount of aid.

In this case, the evidence is somewhat mixed, but pointing toward corroborating the hypotheses that, overall, the countries most susceptible to trading support for aid would get more aid during or immediately after their UNSC memberships in Very Important Years: out of 14 cases, 9 (Bolivia, Brazil, Cape Verde Islands, Czechoslovakia, Ivory Coast, Japan, Morocco, New Zealand, Venezuela) have expected results.

If we include in the average Shares of Total Aid received by each country during or immediately after UNSC membership in Somewhat Important Years, the results for the period 1946-2002 are:

- Ivory Coast and, unexpectedly, Norway get more than three times more aid during and after UNSC membership in Important Years;

- Brazil, Cape Verde Islands and, unexpectedly, Hungary get more aid (from $28 \%$ to $67 \%$ more) during and after UNSC membership in Important Years (that is, Very Important and Somewhat Important Years);

- Morocco gets basically the same average aid in both situations;

- Bolivia, Japan, Djibouti, Pakistan, Spain, Venezuela get less aid in Important Years;

- Czechoslovakia and New Zealand practically get no aid.

Now we have 8 countries (Bolivia, Djibouti, Hungary, Japan, Norway, Pakistan, Spain, Venezuela) with unexpected results. 
Though we should expect that the results would be stronger for Very Important Years, it is still noteworthy that most countries with negative average Agreement Indexes, z-scored (Cape Verde Islands, Hungary, Ivory Coast, Morocco) got more aid in Very Important Years and in Important Years, while countries with positive average Agreement Indexes, z-scored got less aid in Very Important Years (Spain, Pakistan) and in Important Years (Bolivia, Japan, Pakistan, Spain, Venezuela).

In both cases, the most puzzling results are for Pakistan, because Pakistan is not particularly rich, has a positive (though not high) average Agreement Index, z-scored throughout the period, but, in spite of being five times a non-permanent UNSC member, systematically got smaller average Shares of Total Aid during or immediately after UNSC membership both in Very Important Years and in Somewhat Important Years.

\section{Before (1946-1991) and after (1992-2002) the demise of USSR}

Finally, we checked if there would be a major difference before and after 1991. It is possible that, with the end of USSR, political affinity and importance of year of UNSC membership had become less of an issue, but, before that, they might be important. Results are shown in Table 5. 
Table 5. Non-parametric correlation index for Share of Total Aid, Share of Total Aid per GDP per capita, Share of World GDP per capita and Agreement Index, z-scored for selected countries (1946-1991).

\begin{tabular}{|c|c|c|c|c|c|c|}
\hline & & & $\begin{array}{l}\text { Share of } \\
\text { total aid } \\
\text { per GDP } \\
\text { per capita }\end{array}$ & $\begin{array}{l}\text { Share } \\
\text { of } \\
\text { World } \\
\text { GDP }\end{array}$ & $\begin{array}{l}\text { Share of } \\
\text { World } \\
\text { GDP } \\
\text { per capita }\end{array}$ & $\begin{array}{l}\text { Agreement } \\
\text { Index. } \\
\text { z-scored }\end{array}$ \\
\hline \multirow{12}{*}{$\begin{array}{l}\text { Kendall's } \\
\text { tau_b }\end{array}$} & \multirow{3}{*}{$\begin{array}{l}\text { Share of total } \\
\text { aid per GDP } \\
\text { per capita }\end{array}$} & Correlation Coefficient & & $-.066^{*}$ & $-.486^{*}$ & -.037 \\
\hline & & Sig. (1-tailed) & & .014 & .000 & .113 \\
\hline & & $\mathrm{N}$ & 526 & 526 & 526 & 526 \\
\hline & \multirow{3}{*}{$\begin{array}{l}\text { Share of } \\
\text { World GDP }\end{array}$} & Correlation Coefficient & $-.066^{*}$ & & $.275^{* *}$ & $.130^{* *}$ \\
\hline & & Sig. (1-tailed) & .014 & & .000 & .000 \\
\hline & & $\mathrm{N}$ & 526 & 531 & 531 & 531 \\
\hline & \multirow{3}{*}{$\begin{array}{l}\text { Share of } \\
\text { World GDP } \\
\text { per capita }\end{array}$} & Correlation Coefficient & $-.486^{* *}$ & $.275^{* *}$ & & $.288^{* *}$ \\
\hline & & Sig. (1-tailed) & .000 & .000 & & .000 \\
\hline & & $\mathrm{N}$ & 526 & 531 & 531 & 531 \\
\hline & \multirow{3}{*}{$\begin{array}{l}\text { Agreement } \\
\text { Index. } \\
\text { z-scored }\end{array}$} & Correlation Coefficient & -.037 & $.130^{* *}$ & $.288^{* *}$ & \\
\hline & & Sig. (1-tailed) & .113 & .000 & .000 & \\
\hline & & $\mathrm{N}$ & 526 & 531 & 531 & 531 \\
\hline \multirow{12}{*}{$\begin{array}{l}\text { Spearman's } \\
\text { rho }\end{array}$} & \multirow{3}{*}{$\begin{array}{l}\text { Share of total } \\
\text { aid per GDP } \\
\text { per capita }\end{array}$} & Correlation Coefficient & & $-.107^{* *}$ & $-.667^{* *}$ & -.049 \\
\hline & & Sig. (1-tailed) & & .007 & .000 & .131 \\
\hline & & $\mathrm{N}$ & 526 & 526 & 526 & 526 \\
\hline & \multirow{3}{*}{$\begin{array}{l}\text { Share of } \\
\text { World GDP }\end{array}$} & Correlation Coefficient & $-.107^{* *}$ & & $.403^{* *}$ & $.186^{* *}$ \\
\hline & & Sig. (1-tailed) & .007 & & .000 & .000 \\
\hline & & $\mathrm{N}$ & 526 & 531 & 531 & 531 \\
\hline & \multirow{3}{*}{$\begin{array}{l}\text { Share of } \\
\text { World GDP } \\
\text { per capita }\end{array}$} & Correlation Coefficient & $-.667^{* *}$ & $.403^{* *}$ & & $.433^{* *}$ \\
\hline & & Sig. (1-tailed) & .000 & .000 & & .000 \\
\hline & & $\mathrm{N}$ & 526 & 531 & 531 & 531 \\
\hline & \multirow{3}{*}{$\begin{array}{l}\text { Agreement } \\
\text { Index. } \\
\text { z-scored }\end{array}$} & Correlation Coefficient & -.049 & $.186^{*}$ & $.433^{* *}$ & \\
\hline & & Sig. (1-tailed) & .131 & .000 & .000 & \\
\hline & & $\mathrm{N}$ & 526 & 531 & 531 & 531 \\
\hline
\end{tabular}

* Correlation is significant at the 0.05 level (1-tailed).

** Correlation is significant at the 0.01 level (1-tailed).

Source: Authors' compilation and analyses.

Before and during 1991, the correlation between Share of Total Aid per GDP per capita and Agreement Index, z-scored was barely negative (close to zero), but 
insignificant (more than $11 \%$ probability of very low coefficients having been got at by chance); the sign only becomes effectively negative and significant after 1991; particularly, all correlations become significant to the 0.01 level (Table 6).

Table 6. Non-parametric correlation index for Share of Total Aid, Share of Total Aid per GDP per capita, Share of World GDP per capita and Agreement Index, z-scored for selected countries (1992-2002).

\begin{tabular}{|c|c|c|c|c|c|c|}
\hline & & & $\begin{array}{l}\text { Share of } \\
\text { total aid } \\
\text { per GDP } \\
\text { per capita }\end{array}$ & $\begin{array}{l}\text { Share } \\
\text { of } \\
\text { World } \\
\text { GDP }\end{array}$ & $\begin{array}{l}\text { Share of } \\
\text { World } \\
\text { GDP } \\
\text { per capita }\end{array}$ & $\begin{array}{l}\text { Agreement } \\
\text { Index. } \\
\text { z-scored }\end{array}$ \\
\hline \multirow{12}{*}{$\begin{array}{l}\text { Kendall's } \\
\text { tau_b }\end{array}$} & \multirow{3}{*}{$\begin{array}{l}\text { Share of } \\
\text { total aid } \\
\text { per GDP } \\
\text { per capita }\end{array}$} & Correlation Coefficient & & $-.197^{* *}$ & $-.520^{* *}$ & $-.366^{* *}$ \\
\hline & & Sig. (1-tailed) & & .000 & .000 & .000 \\
\hline & & $\mathrm{N}$ & 144 & 144 & 144 & 144 \\
\hline & \multirow{3}{*}{$\begin{array}{l}\text { Share of } \\
\text { World } \\
\text { GDP }\end{array}$} & Correlation Coefficient & $-.197^{* *}$ & & $.485^{* *}$ & $.218^{* *}$ \\
\hline & & Sig. (1-tailed) & .000 & & .000 & .000 \\
\hline & & $\mathrm{N}$ & 144 & 144 & 144 & 144 \\
\hline & \multirow{3}{*}{$\begin{array}{l}\text { Share of } \\
\text { World } \\
\text { GDP per } \\
\text { capita }\end{array}$} & Correlation Coefficient & $-.520^{* *}$ & $.485^{* *}$ & & $.496^{* *}$ \\
\hline & & Sig. (1-tailed) & .000 & .000 & & .000 \\
\hline & & $\mathrm{N}$ & 144 & 144 & 144 & 144 \\
\hline & \multirow{3}{*}{$\begin{array}{l}\text { Agreement } \\
\text { Index. } \\
\text { z-scored }\end{array}$} & Correlation Coefficient & $-.366^{* *}$ & $.218^{* *}$ & $.496^{*}$ & \\
\hline & & Sig. (1-tailed) & .000 & .000 & .000 & \\
\hline & & $\mathrm{N}$ & 144 & 144 & 144 & 144 \\
\hline \multirow{12}{*}{$\begin{array}{l}\text { Spearman's } \\
\text { rho }\end{array}$} & \multirow{3}{*}{$\begin{array}{l}\text { Share of } \\
\text { total aid per } \\
\text { GDP per } \\
\text { capita }\end{array}$} & Correlation Coefficient & & $-.299^{* *}$ & $-.711^{* *}$ & $-.554^{* *}$ \\
\hline & & Sig. (1-tailed) & & .000 & .000 & .000 \\
\hline & & $\mathrm{N}$ & 144 & 144 & 144 & 144 \\
\hline & \multirow{3}{*}{$\begin{array}{l}\text { Share of } \\
\text { World } \\
\text { GDP }\end{array}$} & Correlation Coefficient & $-.299^{* *}$ & & $.623^{* *}$ & $.309^{* *}$ \\
\hline & & Sig. (1-tailed) & .000 & & .000 & .000 \\
\hline & & $\mathrm{N}$ & 144 & 144 & 144 & 144 \\
\hline & \multirow{3}{*}{$\begin{array}{l}\text { Share of } \\
\text { World } \\
\text { GDP per } \\
\text { capita }\end{array}$} & Correlation Coefficient & $-.711^{* *}$ & $.623^{* *}$ & & $.712^{* *}$ \\
\hline & & Sig. (1-tailed) & .000 & .000 & & .000 \\
\hline & & $\mathrm{N}$ & 144 & 144 & 144 & 144 \\
\hline & \multirow{3}{*}{$\begin{array}{l}\text { Agreement } \\
\text { Index. } \\
\text { z-scored }\end{array}$} & Correlation Coefficient & $-.554^{* *}$ & $.309^{* *}$ & $.712^{* *}$ & \\
\hline & & Sig. (1-tailed) & .000 & .000 & .000 & \\
\hline & & $\mathrm{N}$ & 144 & 144 & 144 & 144 \\
\hline
\end{tabular}

** Correlation is significant at the 0.01 level (1-tailed).

Source: Authors' compilation and analyses. 
Though this is in line with SR expectations - the end of the USSR would have rendered political alignment much less relevant-, the value of the political alignment among the sample countries before 1991 is very low, and possibly only coincidental; but the negative correlation between wealth and aid is still significant and high in comparison with political alignment. It seems to be at best a very weak vindication, if at all, of SR expectations.

In order to look at the 'bribery' hypothesis controlling for the change in system polarity and for relevance of year of UNSC membership, we need a different procedure, because Bolivia and Czechoslovakia were not UNSC members between 1992-2002, and Cape Verde Islands and Djibouti were UNSC members only after 1991. Though the numbers here are small and these results can, in themselves, be somewhat misleading, the fact is that, controlling for changes in the systemic distribution of capabilities and for relevance of year of UNSC membership at the same time, results are different (Table 7). 


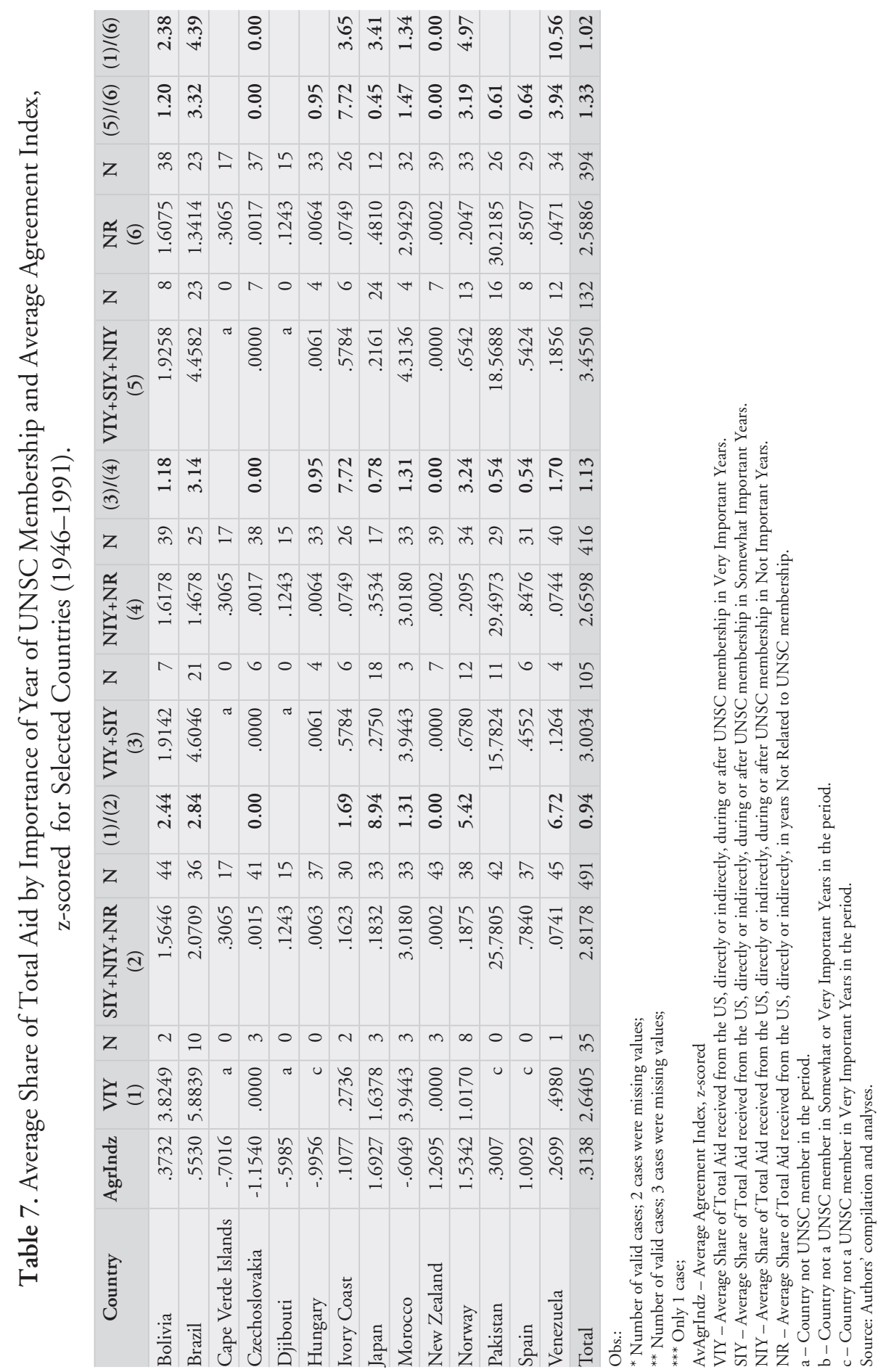


From 1946 to the end of the USSR, excluding Cape Verde Islands, Djibouti, Pakistan and Spain, that were not UNSC members in Very Important Years during those years, we have:

- Czechoslovakia, Hungary and New Zealand practically get no aid at all, which is entirely consistent with our hypotheses;

- In all the other cases, every single country gets at least 30\% more aid during or immediately after UNSC membership in Very Important Years-particularly, Venezuela gets 12 times more aid and Japan gets 9 times more-, which, except for Norway, is totally consistent with our hypotheses;

- Of those 7 cases, 4 get even larger amounts (between 2.84 times and 8.94 times) of additional aid than $\mathrm{K} \& \mathrm{~W}$ found (2.7 times) during or after UNSC membership in Very Important Years;

- Except for Venezuela, the ranking for difference in average Shares of Total Aid for GDP per capita is the same ranking for average Agreement Index, $z$-scored, which is remarkably consistent with our hypotheses.

The same does not apply when we merge the averages for Very Important Years and those for Somewhat Important Years for 1946 through 1991 (excluding Cape Verde Islands and Djibouti, which were not UNSC members in that period), Table 8:

- Czechoslovakia, Hungary and New Zealand again practically get no aid at all, which is entirely consistent with our hypotheses;

- 6 countries (Bolivia, Brazil, Ivory Coast, Morocco, Norway, Venezuela) still get more aid during or after UNSC membership in Very Important Years and Somewhat Important Years, but the variations are much smaller, which still is consistent with our hypotheses;

- In those 6 cases, the ranking for variation in average Shares of Total Aid per GDP per capita is different of that for average Agreement Index, z-scoredwhich is not contradictory with our hypotheses, neither corroborates them;

- 3 countries (Japan, Pakistan and Spain), all with positive average Agreement Index, $z$-scored, get less average Shares of Total Aid during or after UNSC membership in Very Important Years and Somewhat Important Years, which is inconsistent with our hypotheses. 


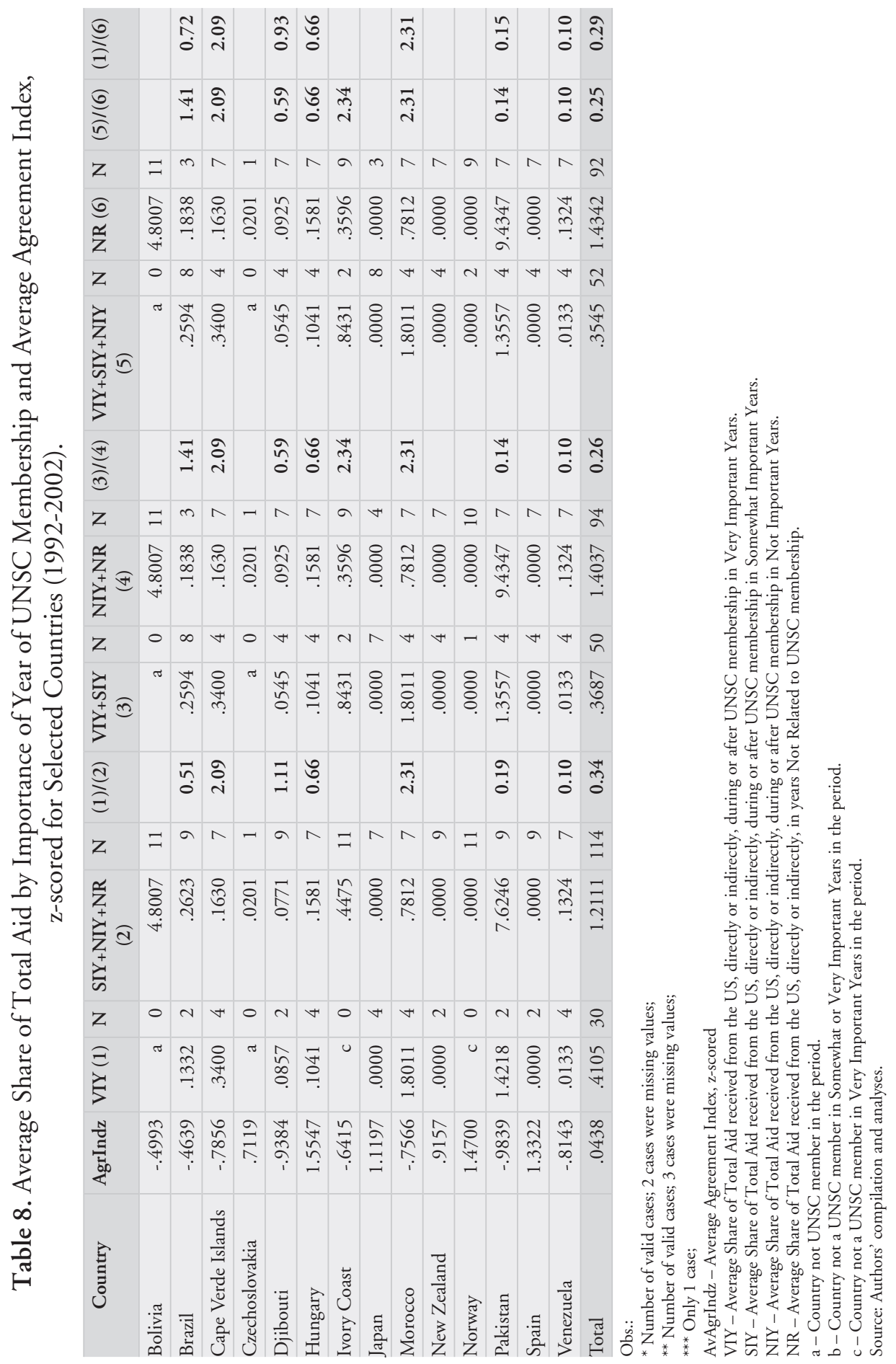


Applying the same procedures for the years 1992 to 2002, we get other results. Excluding Bolivia, Czechoslovakia, Ivory Coast and Norway (not UNSC members in Very Important Years), we find:

- Japan, New Zealand and Spain, which are now rich countries (and close US allies), get no aid at all—a result thoroughly consistent with our hypotheses, but rather unsurprising in itself;

- 3 countries (Morocco, Cape Verde Islands and Djibouti) — all of them with negative average Agreement Index, z-scored - get larger average Shares of Total Aid during or after UNSC membership in Very Important Years, but all by less than 2.5 times;

- 4 countries (Brazil, Hungary, Pakistan and Venezuela) get less aid during or after UNSC membership in Very Important Years, notwithstanding the fact that Hungary has the highest average Agreement Index, z-scored of all the sample countries in this period.

In contrary to what happens in 1946-1991, results are thoroughly replicated when we merge the averages for Very Important Years and those for Somewhat Important Years for 1946 through 1991 (now including Ivory Coast and Norway, which were UNSC members in Somewhat Important Years in this period):

- as above, Japan, New Zealand and Spain, plus Norway, which are now rich countries (and close US allies), get no aid at all—a result thoroughly consistent with our hypotheses, but rather unsurprising in itself;

- 4 countries (Morocco, Cape Verde Islands and Djibouti, plus Ivory Coast) — all of them with negative average Agreement Index, z-scored — get larger average Shares of Total Aid during or after UNSC membership in Very Important Years, but all by less than 2.5 times;

- 4 countries (Brazil, Hungary, Pakistan and Venezuela) get less aid during or after UNSC membership in Very Important Years, notwithstanding the fact that Hungary has the highest average Agreement Index, z-scored of all the sample countries in this period.

This suggests that the end of the Cold War completely erases any evidence in favor of the support-for-aid deal, presumably due to the diminished interest of the US, as the sole remaining superpower. In this case, it seems that, from 1992 to 2002, aid is granted more according to receiving countries' demands than to the giving country interests. 


\section{Conclusion}

Our hypotheses $\mathrm{H} 1$ and $\mathrm{H} 3$ seem valid only when both conditions apply simultaneously: (i) only for voting and aid until 1991 (which corroborates H4); and (ii) only when aid is related to UNSC non-permanent membership in Very Important Years (which is important evidence in favor of H3). From 1992 on, there is no relation between aid granted, directly or indirectly, by the US and either political affinity or membership in the UNSC, no matter its importance in any year. At the same time, $\mathrm{H} 2$ is thoroughly corroborated throughout the whole period.

Since ours is a preliminary assessment, in making sense of our empirical results, we will not call our results "conclusions," but "indications."

Indication 1: The degree of political competition due to the systemic distribution of capabilities is a major factor in explaining great power behavior in an international organization.

Our results support the notion that the demise of USSR and the ensuing more benign international structure (from the US standpoint) brought about a significant change in the US behavior, at least concerning aid-granting.

Indication 2: International organizations are not irrelevant.

If IOs were irrelevant, there would be no point in trying to obtain support by granting aid. Our results suggest that this was actually tried and, in some degree, obtained.

Indication 3: International organizations are not mere extensions of great powers' power.

The evidence suggests this in two ways: (i) the fact that, even during the Cold War, the evidence only supports the support-for-aid hypotheses when related to UNSC membership in Very Important Years and the fact that, otherwise, aid is strongly related to poverty and not to political affinity shows that, most of the time, aid was not granted according to political interest; (ii) the fact that, after 1992, aid continues to be granted without major concern for the relative importance of the year of UNSC membership and, particularly, without any concern with political affinity (actually negatively correlated to $i t$ ) is also a strong indication that other UN objectives (like development, for instance), at least not immediately related to furthering US power, might be at stake.

Actually, in a more favorable international structure (from the US standpoint), US granting behavior is completely in line with IL expectations; should the more extreme versions of SR have it right, we should expect that, in a less-restrained world, a sole superpower would behave even more in line with its own powerpolitics interests. 
Indication 4: A less politically competitive international structure gives smaller countries both a freer hand and less political clout.

After the Cold War, we see that ratios between aid granted during and after UNSC membership in Very Important Years and that granted in other cases are clearly smaller, suggesting a smaller bargaining power brought about by UNSC membership; on the other hand, it seems that poorer countries after the Cold War could oppose the US in the UNGA as they saw fit, and still get some aid.

Indication 5: Many aid receivers don't get a greater share of aid during its non-permanent membership at the UNSC, or immediately after, than in years not related to a non-permanent membership, even when those years of non-permanent UNSC membership were deemed somewhat important.

That somewhat qualifies some K\&W's results while at the same time showing effects stronger than those found there, which seems to indicate that the methodological issues raised before are important. Indeed, the results for our sample of countries suggest that controlling both for the possibility that increases in aid received might be related to variations in the total assistance provided directly or indirectly by the US and for aid received in years not related to UNSC membership by a country significantly affects results.

Finally, one issue was not addressed here: if results for political affinity would change if we control by the votes that the US Department of State considers most important $\mathrm{t}^{20}$. Further analyses should also address that.

Overall, then, our preliminary analysis is consistent with the main thrust of the literature on the subject, and somewhat supports the less extreme versions of Structural Realism, with an important caveat: at least as the US is concerned, a superpower seems to prefer to behave according to Liberal-Institutionalism's expectations, doing otherwise only in special situations. If this result is confirmed, an important line of research would be to check if this is a general trend of great powers' behavior in IOs or a specific feature of the US.

\section{Bibliographic references}

ALESINA, A.; DAVID D. (2000) Who Gives Foreign Aid to Whom and Why? Journal of Economic Growth, Springer, v. 5, n.1, March, 2000, p. 33-63.

AMORIM NETO, Octavio. (2012) De Dutra a Lula: a condução e os determinantes da política externa brasileira. 1. ed. Rio de Janeiro: Elsevier.

DREHER, A; NUNNENKAMP, P; THIELE, R. (2008) Does US aid buy UN general assembly votes? A disaggregated analysis. Public Choice, Zurich, v. 136, n. 1, July, 2008, p. 139-164.

20 The US Department of State issues a yearly report named UN Voting Practices, in which that information is available. 
DREHER, Axel; STURM, Jan-Egbert; VREELAND, James Raymond. (2008) Global Horse Trading: IMF loans for votes in the United Nations Security Council. Available in <http://149.132.120.83/web/corsi/global_capital_markets_\%28international_finance_and_ development\%29277/altro/axel-unsc_imf08.pdf> Accessed in November 11th, 2009.

DREHER, Axel; STURM, Jan-Egbert; VREELAND, James Raymond. (2009) “Development aid and international politics: Does membership on the UN Security Council influence World Bank decisions?” Journal of Development Economics 88 (2009), p. 1-18.

FASULO, Linda. (2009) An Insider's Guide to the UN. New Haven, Yale University Press. 2nd. edition.

FLECK, R. K.; KILBY C. (2006) How Do Political Changes Influence US Bilateral Aid allocations? Evidence from Panel Data. Review of Development Economics, Ames, v. 10, n. 2, May, 2006, p. 210-223.

UNITED STATES AGENCY FOR INTERNATIONAL DEVELOPMENT. US Overseas Loans and Grants (USAID). Disponível em: <http://qesdb.cdie.org/gbk/index.html> Acesso em: 23 de set. 2009.

Grieco, Joseph M. (1993a) “The relative-gains problem for international cooperation”. The American Political Science Review, 87 (3), Sept. 1993, pp. 729-735.

Grieco, Joseph M. (1993b) "Understanding the Problem of International Cooperation: the Limits of Neoliberal Institutionalism and the Future of Realist Theory". in: Baldwin, David A, Ed. (1993) Neorealism and neoliberalism: the contemporary debate. New York: Columbia University Press,. p. 301-338.

Grieco, Joseph M. (1995) "Anarchy and the Limits of Cooperation: A Realist Critique of the Newest Liberal Institutionalism”. in: Kegley, Charles W., Jr., Ed. (1995) Controversies in International Relations Theory: Realism and the Neoliberal Challenge. New York, St. Martin's Press.

JACKSON, Richard L. (1983) The Non-Aligned, The UN, and The Superpowers. New York: Praeger Publishers.

Keohane, Robert O. (1984) After hegemony: cooperation and discord in the world political economy. Princeton (NJ), Princeton University Press.

Keohane, Robert O. (1993) "Institutional Theory and the Realist Challenge After the Cold War". in: Baldwin, David A, Ed. (1993) Neorealism and neoliberalism: the contemporary debate. New York: Columbia University Press,. p. 269-300.

Keohane, Robert; Martin, Lisa. (2000) “The Promise of Institutionalist Theory”. in: Brown, Michael, et al. Theories of War and Peace. Cambridge (Mass.), MIT Press.

KUZIEMKO, I; WERKER, E. (2006a) How Much is a Seat on the Security Council Worth? Foreign Aid and Bribery at the United Nations. 2006a. Manuscrito.

KUZIEMKO, I; WERKER, E. (2006b) How Much is a Seat on the Security Council Worth? Foreign Aid and Bribery at the United Nations. Journal of Political Economy, Chicago, v. 114, n.5, 2006b, p. 905-930.

LIJPHART, Arend.(1963) The analysis of bloc voting in the General Assembly: a critique and a proposal. The American Political Science Review, vol. 57, n. 4, Dec. 1963, p. 902-917. 
LUNDBORG, Per. (1998) Foreign Aid and International Support as a Gift Exchange. Economics and Politics, v. 10, n. 2, July, 1998, p. 127-142.

MADDISON, Angus. (2009) Historical Statistics for the World Economy: 1-2003 AD. Disponível em <http://www.ggdc.net/Maddison/Historical_Statistics/horizontal-file_03-2007. xls>. Acesso: em 15 de Set. de 2009.

MALONE, David M. (2004) The UN Security Council: From the Cold War to the 21st Century. Boldon, Lynne Rienner.

MARÍN BOSCH, Miguel. (2004) Votos y vetos en la Asamblea General de las Naciones Unidas. 2. ed. México: FCE, SRE, 2004.

Martin, Lisa. (1992) "Interests, Power, and Multilateralism”. International Organisation 46 (4), Autumn, 1992, pp. 765-792.

Mearsheimer, John J. (2000a) “The False Promise of International Institutions”. in: Brown, Michael, et al. (2000) Theories of War and Peace. Cambridge (Mass.), MIT Press, 2000 p. 329-383.

Mearsheimer, John J. (2000b) "Back to the Future: Instability in Europe after the Cold War". in: Brown, Michael, et al. (2000) Theories of War and Peace. Cambridge (Mass.), MIT Press, 2000 p. 3-54.

Mearsheimer, John J. (2001) The Tragedy of Great Power Politics. New York, W.W. Norton, 555 pp.

O'NEILL, Barry. (1996) Power and Satisfaction in the United Nations Security Council. Journal of Conflict Resolution, v. 40, n. 2, July, 1996, pp. 219-237.

OLIVEIRA, Raquel de Bessa Gontijo de. (2012) A Relação Brasil-Estados Unidos através dos votos: uma análise da relação Brasil-Estados Unidos através dos padrões de votos na Assembleia Geral das Nações Unidas (1946-2010). Belo Horizonte, mimeo, 2012. (Dissertação de Mestrado apresentada ao Programa de Pós-Graduação em Relaçôes Internacionais da Pontifícia Universidade Católica de Minas Gerais - PUC-MG).

PRANTL, Jochen. (2006) The UN Security Council and Informal Groups of States: Complementing or Competing for Governance? 1.ed. New York: Oxford University Press.

SMITH, Courtney B. (2006) Politics and Process at the United Nations: the Global Dance. 1. Ed. Colorado: Boulder Lynne Rienner.

UNITED NATIONS. (1945) Charter of the United Nations. New York, 1945.

VOETEN, Erik. "United Nations General Assembly Voting Data". Available at : <http://dvn. iq.harvard.edu/dvn/dv/Voeten>. Accessed in November 18, 2009

VOETEN, Erik. (2001) Outside Options and the Logic of Security Council Action. The American Political Science Review, v. 95, n. 4, Dec. 2001.

Waltz, Kenneth N. (1979) Theory of International Politics. New York, McGraw-Hill.

Waltz, Kenneth N. (1993) “The Emerging Structure of International Politics”. in: International Security vol. 18 n. 2, Autumn, 1993, p. 44-79. 
Waltz, Kenneth N. (2000) "Structural realism after the Cold War". in: International Security vol. 25 n. 1, Summer, 2000, p. 5-41.

WITTKOPF, Eugene R. (1973) Foreign Aid and United Nations Votes: A Comparative Study. The American Political Science Review, v. 67, n. 3, Sept., 1973, p. 868-888.

Submitted May 6, 2014

Accepted May 18, 2014

\begin{abstract}
Liberal-Institutionalism and Structural Realism expectations about international organizations are confronted by looking at if and how US-controlled international aid is granted, and particularly if it is related or not to political affinity and to United Nations Security Council (UNSC) non-permanent membership. A preliminary assessment suggests that these relations only hold for the period of the Cold War, and, even then, only when UNSC non-permanent membership is in years in which the Security Council was deemed very important.
\end{abstract}

Keywords: decision-making process; great powers' behavior; international aid; international organizations; International Relations theory; Liberal-Institutionalism; Structural Realism; United Nations; United Nations General Assembly; United Nations Security Council.

\title{
Resumo
}

As expectativas do Institucionalismo Liberal e do Realismo Estrutural sobre as organizações internacionais são confrontadas observando-se se e como é prestada a assistência internacional controlada pelos EUA, e particularmente se esta está relacionada ou não a afinidades políticas e à condição de membro não permanente do Conselho de Segurança da Organização das Nações Unidas (CSONU). Uma avaliação preliminar sugere que essas relações só perduram durante o período da Guerra Fria, e, mesmo então, somente quando a condição de membro não permanente do CSONU ocorre em anos em que o Conselho de Segurança era considerado muito importante.

Palavras-chave: processo de tomada de decisão; comportamento das grandes potências; assistência internacional; organizações internacionais; teoria das Relações Internacionais; Institucionalismo Liberal; Realismo Estrutural; Organização das Nações Unidas; Assembleia Geral da Organização das Nações Unidas; Conselho de Segurança da Organização das Nações Unidas. 